\title{
Antisecretory factor as a potential health-promoting molecule in man and animals
}

\author{
Caterina Ulgheri, Beatrice Paganini and Filippo Rossi* \\ Istituto di Scienze degli Alimenti e della Nutrizione, Facoltà di Agraria, Università Cattolica del Sacro Cuore, \\ Via Emilia Parmense 84, 29100 Piacenza, Italy
}

\begin{abstract}
Antisecretory factor (AF) is a protein secreted in plasma and other tissue fluids in mammals with proven antisecretory and anti-inflammatory activity; its immunohistological distribution suggests a role in the immune system. The expression level and the distribution of AF protein are altered during an immunological response. Exposure to bacterial toxins induces secretion of AF in plasma, probably reflecting a natural defence mechanism to agents causing diarrhoea, thereby contributing to a favourable clinical outcome and disease termination. An increase of AF levels in plasma by dietary means, such as specially processed cereals (SPC), has been demonstrated in human subjects and animals. Administration of SPC to patients affected by inflammatory bowel disease, gastroenteritis and Ménière's disease relieved symptoms and improved quality of life. A recent study showed the positive effect of SPC diet supplementation on prevention of the effects of exposure to low levels of blast overpressure in rats, reducing the extent of intracranial pressure increase and cognitive function impairment. AF-rich egg yolk powder improved health status in children suffering acute and chronic diarrhoea, reducing the frequency and increasing the consistency of stools. This kind of functional food could be used for prophylaxis in populations exposed to a high risk of morbidity and mortality caused by diarrhoea and as a complementary therapy in patients affected by chronic intestinal inflammatory disease to improve well-being. In pig husbandry AF-inducing diets, owing to their antisecretory activity and anti-inflammatory action, are a suitable option as an alternative to antibiotic growth promoters to counteract post-weaning diarrhoea.
\end{abstract}

Antisecretory factor: Diarrhoea: Specially processed cereals: Inflammatory bowel disease

\section{Introduction}

Antisecretory factor $(\mathrm{AF})$ is a $41 \mathrm{kDa}$ endogenous protein which was originally purified in the pig pituitary gland by Lönnroth $e t a l .{ }^{(1)}$ and since then its gene has been cloned and sequenced ${ }^{(2)}$. It has been established that $\mathrm{AF}$ is synthesised in most tissues of mammals and can be found linked to the $26 \mathrm{~S}$ proteasome or free in the cytoplasm and/or nucleus $^{(3)}$. AF has been shown to inhibit enterotoxininduced intestinal hypersecretion in both human and animal subjects $^{(4,5)}$. In a rat intestinal loop model, $1 \mathrm{pmol}$ of purified AF caused a significant reduction of cholera toxin (CT) and Escherichia coli toxin-induced secretion ${ }^{(6)}$. Rapallino et al. ${ }^{(7)}$ hypothesised that $\mathrm{AF}$ may act at the level of intestinal epithelial cells, by regulating chloride homeostasis, thereby possibly counteracting excessive secretion of fluids into the intestinal lumen.
The immunohistological distribution of AF suggests that this protein may play a role in the immune system as an anti-inflammatory agent ${ }^{(8)}$. In rat jejunal loops, $\mathrm{AF}$ inhibited the inflammatory response caused by toxin A from Clostridium difficile ${ }^{(4)}$. Intestinal exposure to bacterial toxins $^{(4)}$ or intake of specific dietary compounds has proved to enhance the antisecretory and anti-inflammatory activity of endogenous $\mathrm{AF}^{(9)}$.

Nowadays, diarrhoeal diseases remain a major global health concern, especially in developing countries where the transmission of infectious gastrointestinal pathogens is favoured by poor hygienic conditions. The 4th Millennium Goal of the UN stated that between the years 1990 and 2015 childhood diarrhoea should be reduced by two-thirds ${ }^{(10)}$. Recent reports state that childhood diarrhoea is responsible for $18 \%$ of all child deaths; it is estimated that two million

\footnotetext{
Abbreviations: AF, antisecretory factor; AGP, antimicrobial growth promoters; CNS, central nervous system; CT, cholera toxin; GABA, $\gamma$-aminobutyric acid; IBD, inflammatory bowel disease; ICP, intracranial pressure; LPS, lipopolysaccharide; LT, labile toxin; SBS, short bowel syndrome; SPC, specially processed cereals.

* Corresponding author: Dr Filippo Rossi, fax +390523 599259, email filippo.rossi@unicatt.it
} 
children die each year due to excessive fluid loss, despite the introduction of oral rehydration therapy ${ }^{(10,11)}$.

Not only is diarrhoeal disease a problem in developing countries, but also it remains an issue of wealthy countries, due to a high incidence of chronic gastrointestinal diseases.

Induction of endogenous AF through nutritional means, in addition to rehydration therapy and/or pharmacological therapy, has been proved to noticeably reduce fluid loss and bowel movements, resulting in an improvement of patients' well-being ${ }^{(9,12,13)}$. A patented hydrothermal process allows cereal kernels to reach an optimal concentration of specific amino acids and oligosaccharides, able to induce endogenous AF secretion ${ }^{(5)}$. These specially processed cereals (SPC) are purified and available under registered trademarks. Included in the diet of patients affected by intestinal chronic inflammatory diseases, SPC improve illness symptoms, reducing daily bowel movements and tissue damage ${ }^{(5)}$.

In livestock production, the efficacy of AF-inducing diets could be of great interest, especially as a tool to counteract post-weaning diarrhoea syndrome in piglets. Indeed, weaning is the most stressful event in piglets' lives, reared in intensive piggeries. Weaning is frequently associated with a reduced nutrient intake, severe growth check, impairment of health status and a higher susceptibility towards infections and gut disorders ${ }^{(14,15)}$.

For more than 50 years, the use of antimicrobial growth promoters (AGP) in animal diets improved growth performance and prevented the side effects of early weaning practice. Increasing concerns about the risk of antibiotic resistance transmission, associated with the widespread agricultural use of antimicrobials, led the European Union to a complete ban of AGP since 1 January 2006. As experienced by the Nordic countries, which banned AGP during the 1980s and 1990s, the main consequences of the elimination of AGP were increased morbidity and mortality of animals, due to an increased incidence of infectious gastrointestinal and respiratory diseases. This has led to an intensification of research to find alternatives to in-feed antibiotics.

AF-inducing diets seem to be interesting alternatives to AGP and a useful tool to improve livestock efficiency, animal health and welfare.

The aim of the present review was to summarise the information about the AF protein and its derivatives, evidencing the beneficial effects of AF-inducing diets on both human and animal health and welfare.

\section{The antisecretory factor molecule}

\section{Genetics}

The AF protein was first purified in rodent extracts of the pituitary gland and intestinal mucosa and later in pig blood $^{(1-3)}$. AF protein is evolutionarily highly conserved and it appears to be a unique protein since no family of AF-like proteins has been identified ${ }^{(5)}$.

Genes coding for AF protein are present in all mammals and homologues of $A F$ genes have been found only in eukaryotic organisms. In the human genome, potential $A F$ genes are expressed in chromosomes 1, 19 and 23, with pseudogenes located on chromosomes 10 and $15^{(5)}$.
The sequence responsible for the antisecretory activity is present only in mammalian proteins while in other eukaryotic organisms the proteins codified by the $A F$ genes act as regulators of proteolytic degradation in the proteasome $^{(2,5)}$. AF protein from plasma is structurally different from the one obtained from the pituitary gland; Lange \& Lönnroth $^{(5)}$ showed that the first is polymeric, while the second is monomeric.

\section{Active site}

Post-translational modifications of AF, such as proteolysis, glycosylation, phosphorylation, or conformational changes, could result in the exposure or hiding of active sites, essential for the exercise of the biological activity ${ }^{(5,16)}$.

Trypsin digestion of the AF protein enhanced two-fold the capability to counteract CT-induced intestinal secretion, indicating that in vivo AF might be activated by hydrolysis ${ }^{(17)}$. The amino acid sequences derived from recombinant human AF trypsin digestion were tested in a rat intestinal loop model in order to identify the active domain of the protein. The antisecretory activity of the truncated forms was related to the presence of a specific amino acid sequence between residues $35^{\prime}$ and $50^{\prime}$ in the N-terminal part; the antisecretory potency was found to be dose dependent. According to Johansson et al. ${ }^{(17)}$, the active region of mammalian AF is probably exerted by a small peptide of eight amino acids (35-IVCHSKTR-42). Compared with other peptides with antisecretory activity, AF appears to be the most potent, since somatostatin is active at nanomolar and enkephalines at micromolar concentrations, while AF is active at 1 pmol dosages ${ }^{(17)}$, since only $10^{-12} \mathrm{~mol}$ of AF are needed to block CT-induced hypersecretion in a rat intestinal loop model.

The smallest molecule with antisecretory and antiinflammatory properties is AF-16, a sixteen amino acid-long peptide comprising the sequence VCHSK TRSNP ENNVG $\mathrm{L}$, synthesised using the solid-phase technique ${ }^{(17)}$.

\section{Receptors}

$\mathrm{AF}$ is present in most body tissues; it can be found in free form in the cytoplasm and/or nucleus or linked to the $26 \mathrm{~S}$ proteasome $^{(3)}$.

Bioinformatic models suggest that the AF protein has a von Willenbrand-like motif in the N-terminal part, between residues 5 and 188, which contains the antisecretory sequence $^{(18)}$. The von Willenbrand-like motif proteins are protein binders; Johansson et al. ${ }^{(18)}$ hypothesised that AF might exert its biological activities by binding to the receptor with its $\mathrm{N}$-terminal part.

With the C-terminal part, AF binds to polyubiquitin, an intracellular protein, via two sites localised between residues 211-230 and 282-301, without involving the von Willenbrand-like motif. This interaction is probably involved in the regulation of the proteolytic processes in the proteasome $^{(18)}$.

Sections from rat brain, double-labelled with antibodies against AF and flotillin-1, showed that there is a high degree of co-localisation between AF and flotillin-1 in neurons and the plexus choroideus ${ }^{(18)}$. Dot-blot analysis has shown that 
AF interacts with flotillin-1 by the means of its N-terminus, carrying the anti-inflammatory and anti-secretory active site.

The flotillin protein family is phylogenetically well preserved and consists of two proteins, flotillin-1 and flotillin- $2^{(19)}$. Flotillins are ubiquitarious: they have a role in endocytosis, participate in signalling, regulate actin cytoskeleton reorganisation and actin-dependent cell adhesion as well as motility ${ }^{(19-21)}$.

Flotillin-1 is an integral membrane protein component of the lipid rafts ${ }^{(18)}$, specialised cell membrane micro-domains rich in cholesterol, sphingolipids and gangliosides ${ }^{(22,23)}$. In the lipid rafts there are proteins of key importance for cohesion and signal transduction such as receptors, cytoskeletal contacts and ion channel complexes ${ }^{(24)}$.

The lipid rafts appear to play a key role in the assembly of signalling processes and to mediate many crucial cellular processes as endocytosis, oxidative stress, apoptosis, ion homeostasis and protein membrane trafficking and turnover $^{(22-25)}$. Though lipid rafts make up a small percentage of the cell membrane, their high concentration of molecules involved in cellular signalling makes them a natural target for bacteria and viruses ${ }^{(26)}$. CT attaches to the intestinal epithelium by binding to ganglioside GM1, which is localised in the lipid rafts as flotillin- ${ }^{(27)}$. Johansson et al. ${ }^{(18)}$ suggested that the interaction between AF and flotillin-1 could affect secretory processes by regulating the localisation of signal proteins, such as receptors, in the lipid rafts.

AF and flotillin-1 are also co-localised in the central nervous system (CNS) and their interaction might affect the AF modulation of glutamatergic and $\gamma$-aminobutyric acid (GABA)ergic synaptic transmissions ${ }^{(18)}$.

\section{Effect of antisecretory factor on the immune system}

In situ hybridisation and immunohistochemical analysis has demonstrated that $\mathrm{AF}$ is expressed in various mammalian $\operatorname{organs}^{(3,8)}$.

Monoclonal TLD antibodies, obtained from rats immunised with cultured microglial cells, were screened by Davidson \& Hickey ${ }^{(8)}$ with the aim to investigate the roles of perivascular and microglia cells in the inflammatory processes in the CNS.

TLD-1A8A is a monoclonal antibody that appears to specifically recognise the $\mathrm{AF}$ molecule cloned from rat microglia; administration of TLD-1A8A in $\mathrm{T}$ cell proliferation or mixed-leucocyte response assays increased T cells proliferation ${ }^{(8)}$. T cell proliferation assays performed with rat serum containing AF showed that AF blocked the TLD-1A8A effect on T cells, suggesting a role for AF in the regulation of $\mathrm{T}$ cell responses ${ }^{(8)}$.

However, the effects on the immunological response observed in vitro did not clarify the nature of the interaction between AF and its antibody. Davidson \& Hickey ${ }^{(28)}$ hypothesised the existence of a receptor for AF on the surface of T cells which might be disrupted by the antibody, blocking the normal suppressing signal. Alternatively, the binding of $\mathrm{T}$ cell membrane-associated AF to the antibody might activate the antigen-presenting cells determining $\mathrm{T}$ cell proliferation ${ }^{(8)}$. Immunohistochemical analysis performed on rat tissue sections treated with TLD-1A8A showed that in lymphoid organs, such as the spleen, thymus and lymph nodes, AF was highly expressed by macrophages and cells with dendritic morphology. In the gut, AF was expressed by scattered macrophages in the connective tissue of the villi and particularly in the Peyer's patch, important in the immune surveillance of the intestinal tract. In the CNS, AF was found in blood vessels and perivascular cells, a bone marrow-derived cell population with immunoregulatory activity $^{(8,29)}$. Davidson \& Hickey ${ }^{(28)}$ observed that macrophages expressed AF even in absence of a direct immunological stimulus, even if the activation of $\mathrm{T}$ cells induced an up-regulation of AF expression in macrophages.

The immunological stimulus, due to experimentally induced autoimmune encephalomyelitis in rats, modified the AF expression level and distribution in the inflamed nervous system, where the expression was enhanced in parenchymal microglia and infiltrating macrophages ${ }^{(28)}$. In inflamed spinal cords, the mRNA expression showed a particular kinetics, with a drop at the onset of the clinical symptoms, a peak in coincidence with the highest disease severity and a decrease to baseline levels in correspondence with the complete recovery of the rats ${ }^{(28)}$. Despite the accumulation of AF-positive leucocytes in the CNS during the course of the disease, no overt changes were apparent in either expression levels or distribution of AF in peripheral organs, such as the spleen and lymph nodes. Since AF levels are at almost undetectable levels on circulating monocytes, Davidson \& Hickey ${ }^{(28)}$ suggested a mechanism whereby AF is up-regulated on these cells at the area of inflammation upon macrophage activation and/or as a result of interaction with activated T lymphocytes. Pro-inflammatory factors, such as lipopolysaccharide (LPS) and interferon- $\gamma$, up-regulated AF expression in rat alveolar macrophages only $72-96 \mathrm{~h}$ after the treatment. The delayed kinetics was attributed to the AF anti-inflammatory effect; the AF up-regulation was associated with a redistribution of the protein within the cell, mainly in the cytoplasm and at the cell surface ${ }^{(28)}$.

Administration of the anti-AF antibody TLD-1A8A to rats with induced experimental autoimmune encephalomyelitis increased the severity of clinical symptoms and the duration of the disease, with up-regulation of proinflammatory cytokine expression (IL-18 and IL-6) and decreased anti-inflammatory IL-10 levels.

Davidson \& Hickey ${ }^{(8,28)}$ hypothesised that the increased AF expression during the course of experimental autoimmune encephalomyelitis might have counteracted the pro-inflammatory environment leading to a reduced tissue damage.

In a recent experiment, performed at the Katholieke Universiteit of Leuven in collaboration with Professor T. A. Niewold, we investigated the anti-inflammatory activity of the AF-16 peptide in LPS-stimulated RAW 264.7 macrophages ( $\mathrm{C}$ ulgheri and TA Niewold, unpublished results). Indeed, macrophages play a critical role in the initiation, maintenance and resolution of inflammation and, upon activation, they release a set of primary inflammatory mediators, such as interleukins, reactive oxygen and nitric oxide species, which are involved in both beneficial and detrimental outcomes in inflammation ${ }^{(30)}$. LPS, as an outer membrane component of bacteria, triggers the secretion of $\mathrm{NO}$, which is extremely reactive and has a wide range of physiological activities involved in the immune response. It was found that treatment with $\mathrm{AF}-16$ reduced $\mathrm{NO}$ 
production by LPS-stimulated macrophages in a dosedependent fashion, with major effects observed at the highest dosages $\left(10^{-4} \mathrm{M}\right)$, showing a mild anti-inflammatory effect only at the highest dosage (Fig. 1).

\section{Effects of antisecretory factor on the nervous system}

The amino acids GABA and glutamate are, respectively, the most common inhibitory and excitatory neurotransmitters in the $\mathrm{CNS}^{(31)}$. Once in the synapse, they act on ionotropic receptors of $\mathrm{GABA}\left(\mathrm{GABA}_{\mathrm{A}}\right)$ and glutamate. In mammals, overstimulation of $\mathrm{GABA}_{\mathrm{A}}$ activity results in central depression, whereas inhibition of $\mathrm{GABA}_{\mathrm{A}}$ receptor activity leads to general excitatory symptoms and convulsions ${ }^{(31-33)}$. Excitotoxicity occurs when ionotropic glutamate receptors are excessively activated; it is characterised by excitatory symptoms and degeneration of neurons ${ }^{(34,35)}$. GABA exerts its effect on both the CNS and enteric nervous system by increasing the $\mathrm{Cl}^{-}$conductance of the cell membrane.

$\mathrm{AF}$ is expressed in the CNS and repeated challenges of rat intestine with $\mathrm{CT}$ were found to increase the expression of $\mathrm{AF}^{(36)}$. In vitro studies, with isolated Deiters' cell membrane from rabbit glia, have advanced the knowledge about the effects of AF and its mechanism of action on the nervous system ${ }^{(7,36,37)}$. AF purified from pig pituitary gland and its peptides were shown to be potent blockers of $\mathrm{Cl}^{-}$ and GABA permeation across isolated rabbit Deiters' cell membrane in a dose-dependent fashion ${ }^{(5)}$. The AF concentration causing half-maximal inhibition was found to be $3 \times 10^{-10} \mathrm{M}$, more than a thousand times lower than $\left[\mathrm{Met}^{5}\right]$ enkephalin, an opioid messenger considered to be one of the most potent inhibitors of GABA membrane permeation in vitro ${ }^{(5)}$.

AF might exerts its effect on the post-synaptic stage since in vitro studies have shown that AF binding to Deiters' cell membrane is reversible while AF had no effect on $\left[{ }^{3} \mathrm{H}\right]$ GABA transport in integral cells ${ }^{(36)}$.

Nipecotic acid and bicuculline, blocker of carriermediated transport of GABA and selective blocker of $\mathrm{GABA}_{\mathrm{A}}$ receptor, respectively, abolished the effects of

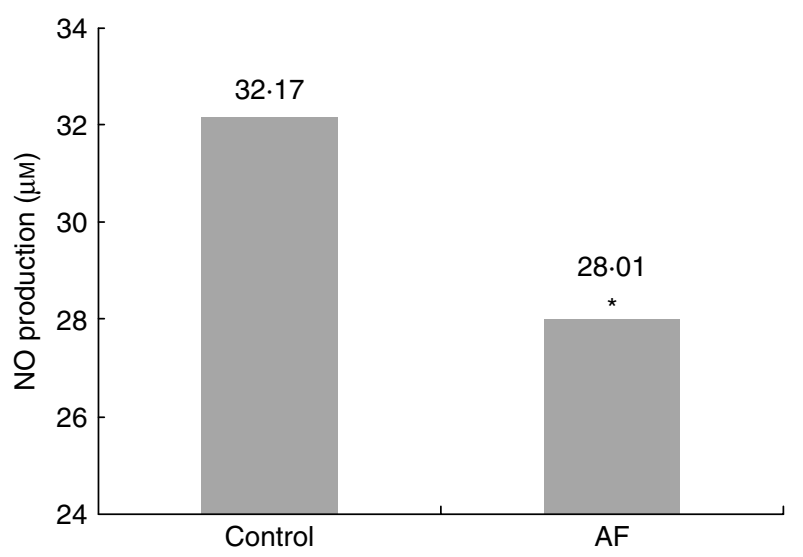

Fig. 1. NO production ( $\mu \mathrm{M})$ by RAW 264.7 macrophages grown with or without (control) $10^{-4} \mathrm{M}$ of antisecretory factor (AF). Values are means. * Mean value was significantly different from that for the control macrophages $(P<0.01)$.
AF on the neuronal membrane, while picrotoxin improved the AF inhibitory effect on $\mathrm{Cl}^{-}$permeation ${ }^{(37)}$. Kim et al. ${ }^{(38)}$ suggested that AF acts as a regulator of chloride homeostasis, thus possibly counteracting an excessive secretion of fluids in the intestinal lumen. AF protein is expressed in rat hippocampus and can pass the blood-brain barrier ${ }^{(38)}$. Extracellular application of exogenous AF peptide to hippocampal slices resulted in a $40 \%$ reduction of GABAergic transmission while glutamatergic transmission was not affected ${ }^{(38)}$. The same effect was also observed in hippocampal slices from rats immunised with CT administration or fed a diet containing hydrothermally processed cereals. To explain the AF-mediated effect on GABA transmission, it was hypothesised that AF might decrease the post-synaptic response by an internalisation of $\mathrm{GABA}_{\mathrm{A}}$ receptors and subsequent degradation in the proteasome ${ }^{(38)}$.

The enteric nervous system, enclosed in the wall of the gastrointestinal tract, regulates motility and fluid transport, mainly without conscious control ${ }^{(39)}$. Intestinal secretion is controlled by local reflexes that probably involve GABAergic neurons. When bound to $\mathrm{GABA}_{\mathrm{A}}$ receptors, GABA has depolarising and excitatory effects on the enteric nervous system ${ }^{(40)}$. In vitro studies showed an inhibitory effect of GABA on motor activity of the guinea-pig distal colon, inducing a relaxation in smooth muscle cells ${ }^{(41,42)}$. Two AF peptides, differing in length and molecular weight and containing the same antisecretory domain, were tested to investigate the role of $\mathrm{AF}$ on colon contractions in the guinea-pig ${ }^{(42)}$. Both peptides increased the frequency of contractions, though at different levels, probably due to conformational differences that might have influenced the interaction with $\mathrm{GABA}_{\mathrm{A}}$ receptors. It was suggested that the positive effect of $\mathrm{AF}$ on the colon contraction frequency during pathological conditions could be a way to protect the mucosa from noxious agents ${ }^{(43)}$. If the antisecretory factor acts as a negative modulator of GABAergic transmission also in the gut, it may counteract hypersecretion by decreasing the activity in secretory reflexes ${ }^{(38)}$.

\section{Antisecretory factor-inducing feed in animal nutrition}

Since the European ban of in-feed antimicrobials, the reduction of post-weaning diarrhoea incidence is a major goal for the pig industry.

The Swedish government ban of AGP in 1986 prompted research for the development of antibiotic-free postweaning feeds for piglet nutrition that were economically and ecologically competitive ${ }^{(5)}$. According to Göransson ${ }^{(44)}$, AF-inducing diets could be an important alternative to AGP and a useful tool to improve livestock efficiency and animal health and welfare.

AF is present in sows' colostrum and milk and there is a correlation between AF content in milk, its level in piglets' blood and the incidence of diarrhoea in the litter ${ }^{(1)}$. AF is transferred from the sow to the fetus across the placenta ${ }^{(45)}$. In piglets, $\mathrm{AF}$ activity in plasma has a cyclic variation; it declines at weaning, reaching the lowest level on the third day post-weaning ${ }^{(6)}$. The onset of diarrhoeal disease is significantly correlated with the low plasma AF activity ${ }^{(5)}$.

Lönnroth \& Lange ${ }^{(1)}$ found that AF production is stress sensitive. In rats, experimentally induced stress or injection 
Table 1. Effects of antisecretory factor (AF)-inducing diet on piglet growth performance, plasma AF content and post-weaning diarrhoea (PWD) incidence

\begin{tabular}{|c|c|c|c|c|c|c|c|}
\hline \multirow[b]{2}{*}{ Farm* $^{*}$} & \multirow[b]{2}{*}{ Pigs $(n)$} & \multicolumn{2}{|c|}{ ADG, $0-35 d(g / d)$} & \multicolumn{2}{|c|}{ AF (units/ml plasma) } & \multicolumn{2}{|c|}{ PWD (\%) } \\
\hline & & Control diet & AF diet & Control diet & AF diet & Control diet & AF diet \\
\hline 1 & 303 & - & - & 0.30 & 0.92 & 60 & 17 \\
\hline 2 & 169 & - & - & 0.31 & 0.91 & 66 & 27 \\
\hline 3 & 40 & 222 & 247 & 0.42 & 0.87 & 35 & 10 \\
\hline 4 & 54 & 266 & 325 & 0.79 & 1.05 & 15 & 4 \\
\hline 5 & 325 & 284 & 380 & 0.76 & 0.94 & 31 & 2 \\
\hline 6 & 144 & 351 & 378 & - & - & - & - \\
\hline
\end{tabular}

ADG, average daily gain.

* Farms 1-5 from Göransson et al. ${ }^{(48)}$; farm 6 from Ulgheri et al. ${ }^{(110)}$

of adrenocorticotropic hormone caused a rapid decrease of AF content in both plasma and pituitary gland ${ }^{(47)}$. According to Lange \& Lönnroth $^{(5)}$ the physiological drop in AF activity at weaning can be inhibited if piglets are fed an AF-inducing diet.

Intestinal fluid accumulation can be caused not only by bacterial enterotoxins or neurohormones but also even by hyperosmotic solutions. Intestinal secretion induced by the intake of solutions enriched with particular sugars, such as mannose and sorbitol, and amino acids such as glycine and alanine, triggered $\mathrm{AF}$ production in rat and pig pituitary glands ${ }^{(47)}$. The concentrations of monosaccharides and amino acids used were low, not able to induce clinical and subclinical diarrhoea. As shown in Table 1, piglets fed a diet with optimised sugar and amino acid content had increased $\mathrm{AF}$ activity in plasma, reduced diarrhoea incidence and improved growth performance: daily weight gain increased from 11.3 to $33.8 \%$; meanwhile, post-weaning diarrhoea incidence decreased by $59.09 \%$ at least ${ }^{(48)}$. An AF-inducing diet, made up of a milk substitute enriched with sugars and amino acids, was shown to be an effective growth promoter in calves, but only if reared in poor hygienic conditions ${ }^{(5)}$.

Wheat and barley kernels subjected to a new patented hydrothermal process achieve a determined content of sugars and amino acids that, once fed to animals or human subjects, triggers AF endogenous secretion. As shown in Table 2, the hydrothermal process increases the glucose level from $0.3 \mathrm{mg} / \mathrm{g}$ to up to $5.3 \mathrm{mg} / \mathrm{g}$ while for fructose, sucrose and maltose the concentration values are raised up from $0.3,8.4$ and 0 to $3 \cdot 1,65.7$ and $9.0 \mathrm{mg} / \mathrm{g}$, respectively. The concentrations of specific amino acids such as lysine, histidine, glutamic acid, tryptophan and isoleucine were also increased by the hydrothermal process ${ }^{(9)}$.

Table 2. Content of sugars and amino acids in cereals before and after the hydrothermal process (from Björck et al. ${ }^{(9)}$ )

\begin{tabular}{lcc}
\hline Content & $\begin{array}{c}\text { Before } \\
\text { the process } \\
(\mathrm{mg} / \mathrm{g} \mathrm{DM})\end{array}$ & $\begin{array}{c}\text { After the } \\
\text { process } \\
(\mathrm{mg} / \mathrm{g} \mathrm{DM})\end{array}$ \\
\hline Glucose & $0.3-0.4$ & $0.6-5.3$ \\
Fructose & $0.3-0.4$ & $0.6-3.1$ \\
Sucrose & $8.4-14.4$ & $36.8-65.7$ \\
Maltose & 0.0 & $4.0-9.0$ \\
Histidine & 0.0 & $0.06-0.25$ \\
Glutamic acid & $0.12-0.20$ & $0.42-0.44$ \\
Lysine & $0.03-0.06$ & $0.15-0.29$ \\
Tryptophan & $0.09-0.22$ & $0.28-0.45$ \\
Isoleucine & 0.0 & $0.05-0.30$ \\
\hline
\end{tabular}

We recently assessed the effects of two different concentrations of SPC, added to a wheat-barley-based diet, on the growth performance of weaned piglets. We found that $6 \%$ of SPC supplementation improved daily weight gain and feed conversion rate of piglets compared with the $3 \%$ supplemented diet and the control group (see Table 1).

Eggs are rich in AF, localised mainly in the yolk; according to Lange et al. ${ }^{(49)}$ the large amount of AF in the yolk could provide the chicken with a kind of protection against gastrointestinal diseases until the animal's capability to actively secrete endogenous AF is restored. Indeed the blood concentration of $\mathrm{AF}$ in chickens decreased from the time of hatching and started increasing at age $21 \mathrm{~d}$. As in pigs, AF concentration in chicken blood is stress sensitive.

AF-rich egg yolk powder, from hens fed SPC, has proved to abolish diarrhoea in children affected by both acute and prolonged diarrhoea ${ }^{(12)}$ and to improve the symptoms in patients affected by inflammatory bowel diseases $(\text { IBD })^{(50,51)}$.

The exact mechanism of action of AF at the cellular level remains unclear. Laurenius et al. ${ }^{(13)}$ suggested that the hydrothermal processing of the cereals might cause an unmasking of epitopes, possible ligands for binding sites in the intestinal mucosa.

\section{Antisecretory factor and gut health}

In a healthy small intestine, villi absorb nutrients while crypts secrete water and electrolytes. The main constituents of intestinal secretion are mucus, enzymes, water, $\mathrm{Na}^{+}, \mathrm{Cl}^{-}$, $\mathrm{HCO}_{3}^{-}$and $\mathrm{IgA}$.

Intestinal secretion is necessary to obtain a chyme with a concentration of nutrients, water and electrolytes optimal for absorption processes and it also might have a function in the homeostatic mechanism such as the control of fluid and acid-base balance in the body ${ }^{(52)}$. In pathophysiological conditions, intestinal secretion protects the mucosa by washing away and diluting harmful substances ${ }^{(53)}$.

During gastrointestinal diseases, regulatory mechanisms of secretion are altered and inflammation and diarrhoea, caused by either infectious or non-infectious aetiologies, are the result of changes in fluid and electrolyte transport in the small and/or large intestine ${ }^{(54)}$.

Enteric pathogens that cause the most severe diarrhoea diseases are rotavirus, Vibrio cholera, Shigella spp., Salmonella spp. and enterotoxigenic E. coli ${ }^{(55)}$. Intestinal hypersecretion caused by $V$. cholera toxin and E. coli 
labile toxin (LT) has been studied in depth in experimental animals. CT-induced diarrhoea has been considered a prototype of enterotoxin-caused diarrhoea, because it does not cause histological changes in the intestine despite substantial rates of net fluid secretion ${ }^{(56)}$. Both CT and LT are heterohexameric molecules which consist of a single A-subunit and five identical B-subunits ${ }^{(57)}$. Despite their similarities, CT and LT induce secretion by different mechanisms at the level of receptors and transductional pathways involved in the secretory response ${ }^{(58,59)}$. Both CT and $E$. coli LT attach to GM1-ganglioside via the B-subunit and the binding itself triggers the toxin internalisation. Inside the cell, the A-subunit catalyses ADP-ribosylation of the Gssubunit of adenylate cyclase, increasing mucosal cAMP level ${ }^{(60)}$. CT and cAMP stimulate active $\mathrm{Cl}^{-}$secretion by activating or inserting $\mathrm{Cl}^{-}$channels into the apical membrane of the crypt cells and inhibit electroneutral $\mathrm{NaCl}$ absorption by decreasing the activity of $\mathrm{Na}^{+} / \mathrm{H}^{+}$and $\mathrm{Cl}^{-}$/ $\mathrm{HCO}_{3}^{-}$exchange in villous cells, without interfering with the glucose-stimulated $\mathrm{Na}$ absorption ${ }^{(55)}$. Studies with fish tetrodotoxin (TTX) showed that CT interacts with the enteric nervous system, inducing the secretion of neurohormones such as 5-hydroxytryptamine and vasoactive intestinal peptide $^{(61,62)}$.

LT is the major virulence factor of enterotoxigenic E. coli; it was found that LT binds to several brush-border galactoproteins only weakly recognised by CT, and it was suggested that binding of LT to this additional receptors might have a role in intestinal secretion pathophysiology ${ }^{(59,63)}$. Recent studies demonstrated that, beyond its ability to bind to different glycolipids on the surface of enterocytes, LT binds to LPS on the surface of E. coli ${ }^{(64)}$. As a result of the LT-LPS surface interaction, more than $95 \%$ of secreted LT is found associated with E. coli outer membrane vesicles, rather than being secreted in a soluble form. LT is able to mediate the internalisation of intact outer membrane vesicles into host cells ${ }^{(65)}$. In addition, competitive binding assays and microscopy with fluorescently labelled enterotoxigenic $E$. coli vesicles revealed that GM1 and LPS binding sites are distinct since the binding process can occur at the same time ${ }^{(64)}$. In cultured human intestinal cells, a third binding substrate for LT is the sugar residues of the receptor molecule of human blood group A antigen ${ }^{(66)}$. According to Mourad et al. ${ }^{(59)}$, LT induces secretion without involving 5-hydroxytryptamine, whose receptors' antagonist had no effect on LT-induced fluid and electrolyte secretion.

C. difficile toxin A has a marked pro-inflammatory effect on the intestinal mucosa, causing fluid accumulation, inflammation and tissue damage. It binds to glycosphingolipid receptors and is internalised in the enterocytes ${ }^{(67)}$. Inside the cell, toxin A exerts enzymic activity, by catalysing glucosylation, triggering the secretion of multiple inflammatory mediators as substance $\mathrm{P}$, histamine, $\mathrm{NO}$ and $\mathrm{PG}^{(68)}$.

Rotavirus infection is one of the leading causes of infantile gastroenteritis. The virus infects the mature enterocytes that line the small intestine and, consequently, it impairs activities of intestinal disaccharides and $\mathrm{Na}^{+}$-solute symports coupled with water transport. Rotavirus protein NSP4 induces a $\mathrm{Ca}$ ion-dependent chloride secretion, disrupts $\mathrm{Na}^{+}$-dependent GLUT1 transporter-mediated reabsorption of water, causes maldigestion of carbohydrates and probably activates the $\mathrm{Ca}$ ion-dependent secretory reflexes of the enteric nervous system ${ }^{(69)}$. The malabsorption of nutrients in the intestine is associated with inhibited water reabsorption and can lead to diarrhoea and malnutrition ${ }^{(69)}$.

Shigellosis is one of the major causes of diarrhoea-related morbidity and mortality in developing countries, transmitted through contaminated food and water as well as through person-to-person contact ${ }^{(70,71)}$. Effects of Shigella spp. infection are inflammation, mucosal ulceration and bleeding of the gastrointestinal tract ${ }^{(71)}$.

The AF protein and its derivatives seem to be the most potent inhibitor of intestinal hypersecretion of various aetiologies. Indeed, less than $1 \mathrm{pmol}$ of human recombinant AF was shown to inhibit CT-induced fluid secretion in a rat model $^{(4)}$. Torres et al. ${ }^{(72)}$ suggested that AF is released as a response to the hypersecretion itself, rather than to the causative agents. Grøndahl et al. ${ }^{(73)}$ tested different AFderived peptides on pig intestinal loops challenged with different secretagogues including CT, LT and 5-hydroxytryptamine and found that AF inhibited intestinal fluid accumulation in the proximal small intestine of CT-treated loops while there was no effect in the distal part.

In vivo experiments conducted with rats demonstrated that repeated exposure to $\mathrm{CT}$ causes a long-lasting overexpression of AF in the intestinal mucosa able to counteract the $C$. difficile toxin A-induced signal, thereby preventing intestinal inflammation and fluid secretion ${ }^{(67)}$. The CTinduced tolerance to $C$. difficile toxin A might be mediated by the enteric nervous system ${ }^{(67)}$. C. difficile toxin A causes the secretion of substance $\mathrm{P}$ that triggers the release of a wide range of chemical mediators by the mucosal enterocytes $^{(74)}$. In the gut, AF is highly expressed in the submucosal T-lymphocytes, suggesting a sort of immunological memory. The antisecretory activity of the AF protein and its derived peptides is usually estimated by an in vivo assay based on the graded inhibition of CT-induced secretion in the intestinal loop model ${ }^{(5,6)}$.

In toxin-challenged experimental animals, the AF antisecretory effect differs with the type of toxin and AF administration route. Human recombinant AF administrated to rats, via the penis dorsal vein or directly into the lumen of an intestinal loop, just before or $1 \mathrm{~h}$ after the $C$. difficile toxin A challenge, reduced mucosal damage and fluid accumulation by $60-70 \%{ }^{(4)}$. Intravenous injection of recombinant AF counteracted the intestinal hypersecretion but not the intestinal epithelial damage caused by okadaic acid ${ }^{(4)}$.

The in vivo assay used to evaluate AF activity in plasma is based on the graded inhibition of CT-induced hypersecretion in ligated loops of the rat small intestine ${ }^{(6)}$. As observed by Johansson et al. ${ }^{(75)}$, this method is reliable and reproducible, it is labour intensive, technically difficult and, furthermore, it requires a large number of experimental animals.

Polyclonal antibodies, raised against linear epitopes of $\mathrm{AF}$ and its derived peptides, were used to investigate the possible changes in the protein structure responsible for its biological activities ${ }^{(76)}$. These antibodies were used to screen the presence of conformational variants of the antisecretory protein in the pig CNS, though they were not able to discriminate between the active and inactive AF form, a great inconvenience since most of the AF present in plasma is in an antisecretory inactive state ${ }^{(76)}$. 
A first step in the development of an in vitro assay, able to detect the AF active forms, has recently been made with the realisation of an ELISA test. This in vitro assay has been developed using monoclonal antibodies raised against human placenta $\mathrm{AF}^{(75)}$. The efficacy of the ELISA test, compared with the in vivo assay (ligated rat intestinal loop), was assessed by analysing AF activity in plasma samples from volunteers who ate the hydrothermally processed cereals. The plasma AF values obtained by ELISA determination correlated well with AF activity as measured by bioassay with the intestinal loops $(r 0.85)^{(75)}$.

\section{Antisecretory factor and inflammatory bowel disease}

IBD is a complex disorder, characterised by chronic inflammation of the gastrointestinal tract, abdominal pain or discomfort, associated with altered bowel habits ${ }^{(77)}$. The two main types of IBD are ulcerative colitis and Crohn's disease. Ulcerative colitis is characterised by chronic mucosal inflammation and epithelial dysfunction in the large intestine, which causes open sores, ulcers and bleeding ${ }^{(78)}$. The main symptoms of ulcerative colitis are inflammation and ulcers in the top layer lining of the large intestine and frequent bloody diarrhoea. Crohn's disease can affect all layers of the intestine in any area of the gastrointestinal tract, from the mouth to the anus, but it most commonly affects the ileum. The swelling extends deep into the lining of the affected organ, causing pain and frequent bowel movement.

IBD is currently considered as a bio-psychosocial disorder with disturbances of motor function, heighted gut sensitivity, and possibly CNS disturbances ${ }^{(79)}$. There is a genetic component in the incidence of IBD, since approximately $20 \%$ of individuals with one form of IBD have a blood relative with $\operatorname{IBD}^{(78)}$. Studies with twins showed that $36 \%$ of monozygotic twins share the disease, compared with only $4 \%$ of dizygotic twins ${ }^{(80)}$. The highest incidence rates and prevalence of IBD have been reported from northern Europe, the UK and North America, though the rates are beginning to stabilise. On the contrary, rates continue to rise in low-incidence areas such as southern Europe, Asia and in most developing countries ${ }^{(81)}$. Curative treatment for IBD has yet to be established; up until now therapeutic focus is on alleviating symptoms ${ }^{(50)}$.

Björck et al. ${ }^{(9)}$ evaluated the effect of an increased endogenous AF secretion on the clinical outcome in patients suffering from IBD. Patients with long-lasting ulcerative colitis or Crohn's disease received a diet containing either placebo cereals or SPC, without changing food habits and conventional medical treatment ${ }^{(9)}$. The outcomes were evaluated by analysing objective and subjective data. Every patient kept a diary to daily record the number of bowel movements and stool consistency, and clinical improvement or clinical deterioration was plotted as percentages on a visual analogue scale score and expressed as percentage of change. The study demonstrated that a diet supplemented with SPC was able to induce an increase of AF in the plasma of patients suffering from IBD. An increased AF level in plasma was associated with an improvement of patient welfare, reduced frequency of bowel movement and solid stools. Rectal biopsies analysed by immunohistochemistry showed that SPC supplementation induced a larger number of AF-positive cells compared with biopsies from the patients receiving the placebo cereals. However, a correlation was found between AF content in plasma and biopsy cell staining. No effects were observed on C-reactive protein in plasma. The AF values in plasma declined slowly after the end of the experiment.

The influence of orally administrated AF, provided by egg yolk with a high AF content, was evaluated in a randomised double-blind study ${ }^{(50)}$. The study involved twenty patients with acute attacks of ulcerative colitis receiving $\mathrm{AF}$ or placebo treatment as a supplement to the conventional therapy usually performed. The 'AF therapy' was shown to have a positive effect on the inflammatory reaction of colonic mucosa. Rectal biopsy analysis evidenced a reduction in the relative number of neutrophils and eosinophil granulocytes in the AF group while no effect on intestinal secretion was observed ${ }^{(50)}$. The study concluded that AF, used as a supplement to conventional pharmacological and nutrition therapies, can help to alleviate inflammation as shown by rectal biopsies $^{(50)}$. Passive administration of AF by the means of an AF-rich egg yolk powder, followed by active induction through a diet supplemented with SPC, induced the regression of Crohn's disease in a patient with longstanding disease, resected colon and not responsive to conventional pharmacological treatment ${ }^{(51)}$. However, Ekesbo et al. ${ }^{(2)}$ reported no additional beneficial effects of SPC diet supplementation in a placebo-controlled diet study conducted with patients affected by irritable bowel syndrome, which received placebo cereals or active AFinducing cereals. It was noted that general conditions in both groups, measured by a visual analogue scale score, improved regardless of which diet was consumed, probably because of a good fibre amount of the diets, which may have had a bulking effect and so reduce diarrhoea $^{(82)}$. However, in the patients with the most severe diarrhoea symptoms, the SPC supplementation increased AF blood levels and led to an improvements in symptoms ${ }^{(82)}$.

\section{Antisecretory factor and short bowel syndrome disease}

Short bowel syndrome (SBS) can appear after intestinal surgery or radiation injury, or can result from loss of function due to vascular insufficiency. Major outcomes are malnutrition and dehydration caused by malabsorption of fluid, electrolytes, minerals and nutrients ${ }^{(83)}$. SBS is often associated with intestinal failure requiring parenteral nutrition, impairment of health-related quality of life and morbidity ${ }^{(83-85)}$.

Lange et al. ${ }^{(86)}$ performed a study on patients with resected intestine and found that the extent of AF activity and the ability to maintain a high level of plasma AF after SPC treatment are significantly correlated with the length of the remaining small intestine. The study found that a length of at least $100 \mathrm{~cm}$ of small intestine is required to induce an improvement of AF activity by dietary means and the presence or absence of the large intestine appeared to not affect AF activity. 
Pagoldh et al. ${ }^{(87)}$ conducted a double-blind trial to investigate the effects of diet supplemented with SPC or with non-processed cereals on health-related quality of life in a heterogeneous group of patients affected by SBS of various aetiologies. Patients differed by short bowel length and intestinal surgical techniques. Compared with SPC, the nonprocessed cereals were more effective in reducing daily faecal volume, especially in patients with ulcerative colitis, probably due to the high content of gel-forming dietary fibre that improved fluid absorption. The surgical techniques influenced the clinical effects of the cereal supplementation $^{(87)}$. Moreover, the effects of the diet supplementation were more evident in the last part of the trial, probably due to a sensitisation process of the mucosa, which was independent from the type of cereals used in the first part of the trial ${ }^{(87)}$. According to the authors, an interesting approach to SBS would be a diet supplementation targeting increased viscosity of the intestinal content that could prolong the transit time and thus improve the uptake of nutrients ${ }^{(85)}$.

\section{Antisecretory factor and endocrine diarrhoea}

Endocrine diarrhoea is caused by an imbalance of specific hormones which inhibit water and electrolyte absorption and/or increase fluid secretion or stimulate motility. The most important hormones involved in the regulation of intestinal secretion are vasoactive intestinal peptide, serotonin, substance $\mathrm{P}, \mathrm{PGE}_{2}$, calcitonin, thyroxin and pancreatic polypeptide hormone ${ }^{(88)}$

Carcinoid syndrome and medullary thyroid carcinoma can lead to an alteration of the hormone balance. Carcinoid syndrome refers to a range of symptoms that occur as a result of carcinoid tumours. Carcinoid tumours originate in the cells of the neuroendocrine system, and could occur anywhere along the gastrointestinal tract and in the lungs and are characterised by the production of serotonin (5-hydroxytryptamine $)^{(89)}$. The syndrome is characterised by endocrine-induced diarrhoea with flushing and bronchospasm, caused by the tumour's ability to secrete vasoactive peptides ${ }^{(88)}$. Medullary thyroid carcinoma is a neuroendocrine tumour that develops in the thyroid $\mathrm{C}$ cells and occurs either as an erratic event or secondary to a germline mutation with an autosomal dominant pattern of inheritance ${ }^{(90)}$. Thyroid $\mathrm{C}$ cells are responsible for the production of both calcitonin and carcinoembryonic antigen $^{(91)}$. Neuroendocrine tumours may induce severe persistent diarrhoea, sometimes therapy-resistant ${ }^{(13,92)}$. Laurenius et al. ${ }^{(13)}$ investigated the effects of AF therapy, AF-rich egg yolk powder or SPC on patients suffering from endocrine diarrhoea due to midgut carcinoid syndrome or metastasising medullary thyroid carcinoma. The study showed that even though the severely ill patients were optimally medicated, several of them responded positively to the AF therapy ${ }^{(13)}$. Passive intake of AF had positive effects on the frequency of bowel movements, indicating that AF was still active after passing the upper gastrointestinal tract. Compared with the passive $\mathrm{AF}$ therapy, the SPC therapy required a larger intake volume, which was difficult to reach in severely ill patients ${ }^{(13)}$. Thus AF-rich egg yolk powder could be the best option for patients who are not able to ingest large amounts of food.
The main clinical outcomes obtained by using the AF-inducing diets in patients affected by irritable bowel syndrome, IBD and SBS are summarised in Table 3.

\section{'Antisecretory factor-therapy': a tool to reduce childhood diarrhoea?}

As previously stated, diarrhoea remains a problem amongst children especially in developing countries, in some cases being even life threatening. Severe malnutrition and infections are the main cause of the children's premature and avertable deaths ${ }^{(93)}$. Diarrhoea can be prevented by improving hygienic conditions, through vaccination and encouraging mothers to breastfeed their infants ${ }^{(94)}$. Breast milk is easily digestible and contains antibodies that can protect the infant from bacterial and viral infections. Furthermore, it aids the development of the child's immune system. According to Ziyane ${ }^{(95)}$, exclusively breastfed infants under 2 months are twenty-five times less likely to die of diarrhoea-related illness than non-breastfed infants. However, in many diarrhoea cases breast-feeding alone does not suffice ${ }^{(96)}$

In a study conducted in Pakistan on children suffering from acute and prolonged diarrhoea episodes, it was found that when given B 221, a medical food based on AF-rich egg yolk powder, the incidence of diarrhoea subsided ${ }^{(12)}$ (see Table 3). The study, which lasted 3 d, involved 240 children from 6 to 24 months; every $5 \mathrm{~h}$ they were randomly given $2 \mathrm{~g}$ of B 221 or placebo (regular egg yolk powder), dissolved in rehydration solution. In children suffering from acute diarrhoea (less than $7 \mathrm{~d}$ of diarrhoea illness), the $\mathrm{AF}$ administration improved frequency and consistency of the stools, the clinical outcome after $3 \mathrm{~d}$ was positive for $83 \%$ of the children fed B 221, while the response to placebo was positive in only $54 \%$ of children ${ }^{(12)}$. In children with prolonged diarrhoea, B 221 treatment resulted in a $91 \%$ successful clinical outcome, compared with the placebo group which only had a $63 \%$ success rate ${ }^{(12)}$.

As demonstrated by Zaman et al. ${ }^{(12)}$, B 221 counteracted diarrhoea of different aetiologies, since it was unlikely that the children involved in the study were infected by the same agent. Dosing and mode of administration of B 221 are still yet to be understood, but according to the authors, a higher dosage might be useful in the management of acute diarrhoea in children, especially in developing countries, avoiding the appearance of prolonged diarrhoea, with its threatening consequences ${ }^{(12)}$.

Svensson et al. ${ }^{(97)}$ found that AF can be induced in maternal milk by hydrothermally processed cereal intake. Furthermore, the AF-inducing diet prevented mastitis, a painful infection and inflammation of the breast tissue, probably due to the anti-inflammatory properties of AF. Thus, SPC intake in lactating women might achieve the double goal of preventing mastitis in the mothers and diarrhoea in children.

\section{Antisecretory factor-inducing foods in Ménière's disease}

An increase of AF in plasma has been found to reduce symptoms in patients suffering from Ménière's disease, a disturbance of the inner ear that can affect hearing and 


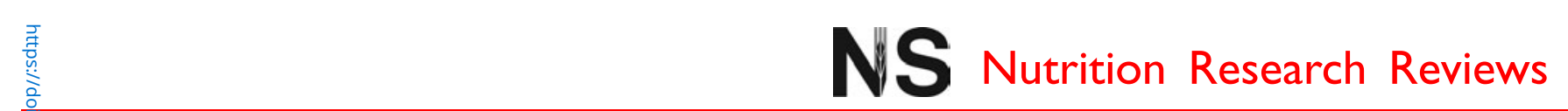

Table 3. Specially processed cereal (SPC) supplementation and main outcomes in subjects suffering from diarrhoea or bowel diseases

\begin{tabular}{|c|c|c|c|c|c|c|}
\hline Study & Study population & Age & Subjects $(n)$ & Treatments & Length of study & Effect \\
\hline \multicolumn{7}{|c|}{ Diarrhoea of different aetiologies } \\
\hline $\begin{array}{l}\text { Laurenius et al. } \\
(2003)^{(13)}\end{array}$ & $\begin{array}{l}\text { Midgut carcinoid } \\
\text { syndrome or } \\
\text { metastasising MTC }\end{array}$ & 57 years & 8 & $\begin{array}{l}\text { 1st period: AF-rich egg yolk for } \\
4 \text { weeks } \\
\text { 2nd period: double-blind } \\
\text { cross-over period with SPC } \\
\text { and control cereals for } \\
6 \text { weeks }\end{array}$ & 17 weeks & $\begin{array}{l}\text { First period: decreased bowel movements } \\
\text { Second period: increased stool consistency }\end{array}$ \\
\hline $\begin{array}{l}\text { Zaman et al. } \\
(2007)^{(12)}\end{array}$ & $\begin{array}{l}\text { Acute diarrhoea } \\
\text { and prolonged } \\
\text { diarrhoea }\end{array}$ & $\begin{array}{l}6-24 \\
\text { months }\end{array}$ & 240 & $\begin{array}{l}2 \mathrm{~g} \text { of either regular egg yolk } \\
\text { or } \mathrm{AF} \text {-containing egg yolk } \\
\text { (B 221) every } 5 \mathrm{~h} \text { along } \\
\text { with an oral rehydration } \\
\text { salt solution }\end{array}$ & $3 d$ & $\begin{array}{l}\text { Positive clinical outcomes in stool frequency } \\
\text { and consistency }\end{array}$ \\
\hline \multicolumn{7}{|c|}{ Inflammatory bowel disease and irritable bowel syndrome } \\
\hline $\begin{array}{l}\text { Erikson et al. } \\
(2003)^{(50)}\end{array}$ & $\begin{array}{l}\text { Acute ulcerative } \\
\text { colitis }\end{array}$ & $\begin{array}{l}18-70 \\
\text { years }\end{array}$ & 20 & $\begin{array}{l}2 \mathrm{~g} \text { of } \mathrm{AF} \text {-rich egg yolk drinks } \\
\text { four times per d or placebo } \\
\text { treatment in addition to the } \\
\text { standard pharmacological } \\
\text { therapy }\end{array}$ & 2 weeks & $\begin{array}{l}\text { Less inflammation in rectal biopsies, } \\
\text { persistent effects after the end of } \\
\text { the treatment. No effect on stool weight }\end{array}$ \\
\hline $\begin{array}{l}\text { Finkel et al. } \\
(2004)^{(111)}\end{array}$ & $\begin{array}{l}\text { Crohn's disease } \\
\text { Ulcerative colitis }\end{array}$ & 16 years & 2 & $\begin{array}{l}54 \mathrm{~g} \mathrm{SPC} / \mathrm{d} \text { in addition to } \\
\text { the standard } \\
\text { pharmacological therapy }\end{array}$ & 2 weeks & $\begin{array}{l}\text { First period: increase in } \mathrm{Hb} \text {, decrease } \\
\text { in intestinal permeability and } \\
\text { improvement of clinical symptoms } \\
\text { Second period: decrease in loose } \\
\text { stools and improvement of general } \\
\text { well-being }\end{array}$ \\
\hline $\begin{array}{l}\text { Erikson et al. } \\
(2003)^{(51)}\end{array}$ & $\begin{array}{l}\text { Crohn's disease } \\
\text { and SBS }\end{array}$ & 38 years & 1 & $\begin{array}{l}\text { AF-rich egg yolk powder } \\
\text { four times per d } \\
\text { On day } 4 \text { : ground SPC } \\
\text { administered }(0.5 \mathrm{~g} / \mathrm{kg} \\
\text { body weight per } \mathrm{d}) \\
\text { On day } 10 \text { : unground SPC } \\
\text { given to patient }(1 \mathrm{~g} / \mathrm{kg} \\
\text { body weight per } \mathrm{d})\end{array}$ & $\begin{array}{l}2 \text { weeks } \\
14 \text { weeks }\end{array}$ & Average daily stools decreased by $80 \%$ \\
\hline $\begin{array}{l}\text { Ekesbo et al. } \\
(2006)^{(82)}\end{array}$ & $\begin{array}{l}\text { Irritable bowel } \\
\text { syndrome }\end{array}$ & 44 years & 62 & $\begin{array}{l}100 \mathrm{~g} \mathrm{SPC} \text { or placebo } \\
\text { cereal per } \mathrm{d}\end{array}$ & 8 weeks & $\begin{array}{l}\text { Overall improvement in symptoms } \\
\text { irrespective of diet }\end{array}$ \\
\hline \multicolumn{7}{|r|}{ ( } \\
\hline $\begin{array}{l}\text { Lange et al. } \\
(2003)^{(86)}\end{array}$ & $\begin{array}{l}\text { Crohn's disease } \\
\text { and SBS }\end{array}$ & 45 years & 6 & $54 \mathrm{~g} \mathrm{SPC} / \mathrm{d}$ & 2 weeks & $\begin{array}{l}\text { Increased AF level in plasma of patients } \\
\text { with at least } 3 \mathrm{~m} \text { of small intestine length }\end{array}$ \\
\hline $\begin{array}{l}\text { Pagoldh et al. } \\
(2008)^{(87)}\end{array}$ & SBS & 50 years & 26 & $\begin{array}{l}\text { Randomised double-blind, } \\
\text { cross-over multicentre } \\
\text { prospective study. } \\
\text { Patients received SPC } \\
\text { or placebo cereals then } \\
\text { treatment was switched } \\
\text { between groups }\end{array}$ & $\begin{array}{l}12 \text { weeks for } \\
\text { each arm of } \\
\text { the study with } \\
6 \text { weeks of } \\
\text { wash-out }\end{array}$ & $\begin{array}{l}\text { Faecal volume significantly decreased } \\
\text { after normal cereal intake, no effect } \\
\text { of SPC. Results strongly affected by } \\
\text { surgical methods used on the patients }\end{array}$ \\
\hline
\end{tabular}


balance, characterised by episodes of vertigo, tinnitus and progressive hearing loss ${ }^{(98)}$. It was first hypothesised that endolymphatic hydrops causes dilation of the cochlear duct affecting the endolymph drainage process. Recent findings suggest that impaired production or resorption of endolymph and/or transport across membranes appear to be major factors in the pathophysiology of Ménière's disease ${ }^{(98,99)}$. Dysfunctions of many structures of the inner ear and of the sympathetic nervous system are likely to be involved in creating the symptoms of this disease.

Experimental evidence about the role of $\mathrm{AF}$ as a regulator of fluid transport across the mucosal membranes and its anti-inflammatory properties led Hanner et al. ${ }^{(98)}$ to perform a clinical pilot study on patients suffering from Ménière's disease, designed to investigate the effect of increased AF plasma concentration on the frequency and extent of vertigo, which are the main symptoms of this disease. The study required that the patients received $1 \mathrm{~g}$ $\mathrm{SPC} / \mathrm{kg}$ body weight per d, divided into two to three dosages over 2-4 weeks. Patients were instructed to keep a diary regarding their subjective symptoms, including frequency, duration of vertigo and fluctuations of hearing. Although the study was performed on a small number of patients, the results were interesting since in about $50 \%$ of patients the attacks of rotatory vertigo diminished or completely disappeared, with reduced final American Academy of Otolaryngology-Head Neck Surgery (AAO-HNS) functional level scale $(1995 \text {; range } 1-6)^{(98)}$. Even if there was a positive correlation between plasma AF activity after the treatment and the reduction of vertigo $(r 0.65 ; P=0.001)$, the response to the diet was individual and not related to the severity of the symptoms ${ }^{(98)}$. The findings of the study confirmed that an AF-inducing diet could be useful in some Ménière's disease patients and also reinforced the authors' idea that AF could be involved in inner ear homeostasis. Following the success of the pilot study, Hanner et al. ${ }^{(99)}$ performed a double-blind study on a larger number of patients ( $n$ 51) for a longer period of time (3 months). Patients were randomly assigned to two groups: a control group which received placebo cereals and the SPC group. In the SPC group, fourteen of the twenty-seven patients experienced a decrease in their symptoms, while in the control group only two participants reported decreased vertigo severity ${ }^{(99)}$. Once the double-blind arm of the study was concluded, the participants of the control group were offered the option to receive the active cereal treatment for a further 3 months: twenty-two patients accepted; of these, seventeen had alleviated symptoms. According to Hanner et al. ${ }^{(99)}$, the results from the open arm of the study might have been influenced by the expectations of the patients. In both trials the feeding treatment had no effects on the clinical otoneurological status of patients, assessed before and after the treatment by pure tone average and speech audiometry tests. Therefore, the SPC treatment exerted its effect only on the vertigo component of the disease. A clear explanation of the mechanism of action of AF remains unknown; however, many experiments and clinical studies indicate that AF can normalise water and ion transport. It has been shown that AF interacts with the lipid raft protein flotillin- ${ }^{(18)}$, and they are both expressed in the inner ear of the rat, as well as the human cochlea and endolymphatic saccus ${ }^{(16,18,98)}$. Hanner et al. ${ }^{(99)}$ suggested that the interaction between $\mathrm{AF}$ and flotillin-1 might cause a down-regulation or a reorganisation of aquaporin channels, thus regulating the homeostasis of endolymph.

\section{New insight on antisecretory factor properties}

Brain oedema, haemorrhage, and obstruction or derangement of the blood-brain barrier can lead to increased intracranial pressure (ICP) that can damage brain function, resulting in inflammation, with possible persistent neurological and psychiatric malfunctions ${ }^{(100-103)}$. The extent of brain damage is related to the severity and length of ICP increase $\mathrm{e}^{(104)}$.

In humans, blast-related brain injuries are known to cause brain oedema, vasospasm and intracranial haemorrhage ${ }^{(105)}$. The current therapeutic options applied in counteracting elevated ICP are not indicated at pressure levels lower than $25 \mathrm{mmHg}$. However, less is known about the medium- and long-term effects of levels of ICP lower than the treatment threshold on physical and psychological functioning of patients ${ }^{(106)}$. The effects of exposure to low and mild blast levels on brain injury is increasingly of interest due to the involvement of large numbers of troops in the Afghani war, where soldiers are often subjected to traumatic brain injury without damage to the head ${ }^{(102)}$. It was recently reported that in a rat model low blast overpressure in a shock tube (10-30-60 kPa) impaired cognitive functions, assessed by the Morris water maze, and caused an elevated ICP in a dose-dependent manner ${ }^{(101)}$. The same experiment was repeated with rats fed or not a diet supplemented with $20 \%$ of hydrothermally processed barley ${ }^{(102)}$. The study showed that the inclusion of hydrothermally processed barley in the rats' diet prevented the impairment of cognitive function and drastically reduced the ICP elevation. The peak of ICP was reached $10 \mathrm{~h}$ after the rats were exposed to both 30 and $60 \mathrm{kPa}$, though in rats exposed to $60 \mathrm{kPa}$ there was a first smaller peak after $10 \mathrm{~min}$. At $10 \mathrm{~h}$ after the overpressure exposure, the mean ICP in rats of the control group subjected to 30 and $60 \mathrm{kPa}$ was raised by 90 and $145 \%$, respectively, while in rats fed hydrothermally processed barley the ICP increased by 60 and $50 \%$, respectively. The feed treatments had no effect on the initial peak, recorded after $10 \mathrm{~min}$ from the exposure at $60 \mathrm{kPa}$. Säljö et al. ${ }^{(103)}$ suggested that the diet supplementation with hydrothermally processed barley reduced brain oedema but the mechanisms behind this protective effect remain unknown.

In a rat experimental model of herpes simplex encephalitis, induced by type 1 virus (HSV-1), AF-16 peptide was used to suppress the raised $\mathrm{ICP}^{(104)}$. The intranasal instillation of AF-16 peptide granted a complete rescue of rats receiving $25 \mu \mathrm{g}$ twice daily from the 4th day after infection. Prevention of neurological malfunctions, usually associated with encephalitis, was found to be dose dependent. In rats receiving $1 \mu \mathrm{g}$ AF-16 twice daily, starting immediately after the infection, there was a moderate mortality, while in animals of the untreated group the mortality was about $90 \%{ }^{(104)}$. The AF-16 peptide reduced the ICP increase and fluctuations, and also abolished the pressure peaks in treated rats. Jennische et al. ${ }^{(104)}$ suggested that the AF-16-mediated suppression of increased ICP in 
infected rats to a non-injurious level might be the cause of abrogated neurological malfunctions.

\section{Summary and conclusions}

In recent years, nutrient content has ceased to be the main goal of nutrition, both for man and animals. Food and feeds are now considered as possible tools to improve health and wellness. Well-known foods, such as grains, tomatoes and milk, have been studied for health-promoting activities of nutrients such as $\beta$-glucans, lignans, lycopene or conjugated linoleic acid.

In healthy individuals, the AF protein is secreted in plasma and other body tissues, probably in a biologically inactive state. Exposure to bacterial toxins induces activation of plasma AF, probably reflecting a natural defence mechanism against agents causing diarrhoea, thereby contributing to a favourable clinical outcome and disease termination ${ }^{(67)}$. The possibility to stimulate AF secretion, by means of processed cereals, and exploit its positive effects on alleviating symptoms in patients suffering from intestinal chronic inflammatory diseases, diarrhoea or affected by Ménière's disease, has been demonstrated in several studies and, although 'AF therapy' cannot be considered a real therapy, its efficacy in reducing symptoms resulted in improvement of patients' life quality. Furthermore, the inclusion of SPC in the diet of lactating women could be exploited in order to reduce intestinal disorders in suckling children, particularly in developing countries, where breast-feeding is highly recommended and the access to anti-diarrhoeal drugs and/or rehydrating solutions is poor. As suggested by Zaman et al. ${ }^{(12)}$, these active cereals can be used as prophylaxis in highly exposed populations during the diarrhoea season. AF-rich egg yolk gives the opportunity of a direct fast administration of the AF molecule to young children and to individuals with impaired food consumption.

A recent study showed the positive effect of SPC diet supplementation on prevention of the negative effects of exposure to low levels of blast overpressure in rats, where the extent of ICP increase and cognitive function impairment were improved ${ }^{(103)}$. So far, there are few studies on the effects of blast-related brain injuries and their effects on brain function in the long-term period, but their prevention by dietary tools is an interesting perspective. Indeed, cereals are part of daily food intake in many countries, so it could be easy to improve the consumption of active cereals, particularly by individuals exposed to a high risk of blast-related brain injuries such as soldiers during training sessions or conflict. They also might be helpful for individuals subjected to the risk of ICP increase, as patients affected by brain pathologies such as tumours in conditions of sudden pressure changes, such as during long flights, or exposed to overpressure as divers.

In pig farming, intensive breeding conditions often expose animals to such stress that they have a negative impact on their health and welfare. Indeed, early weaning exposes the piglets to simultaneous nutritional, social and environmental stresses when the immune and the gastrointestinal systems of the piglets have not completely reached functional development. This situation often results in low voluntary feed intake, severe growth reduction and can lead to an impairment in health status, to a major susceptibility towards infections and gut disorders. Weaned piglets frequently show malabsorption syndrome, characterised by increased excretion of carbohydrates and fatty acids in faeces, watery stools and degeneration of the intestinal epithelium. Moreover, opportunistic pathogens such as enterotoxigenic $E$. coli can take advantage from the poor health condition of piglets affected by non-infectious diarrhoea and cause the post-weaning diarrhoea syndrome.

For a long time, the employment of in-feed antimicrobials has been strategic in reducing the negative effects of premature weaning on piglets' health and growth performance.

Since the complete ban of in-feed antimicrobials in 2006, several nutritional approaches and alternative substances have been proposed but, so far, none of these have been shown to be as effective as antibiotics on growth promotion and disease prevention of food animals.

Among the alternatives proposed, immunomodulating substances are gaining interest, since the correct development of both the innate and acquired immune system of the piglets is strategic in determining the outcomes of a large exposure to antigens and stress conditions, typical of weaning ${ }^{(107)}$. AF-inducing diets such as those including hydrothermally processed cereals appear to be suitable candidates as replacers of antibiotic growth promoters.

Indeed, AF is present in sows' milk and a correlation between $\mathrm{AF}$ concentration in milk and diarrhoea in the offspring has been proved. Several in vitro and clinical studies have found evidence for its potent capability to counteract intestinal fluid imbalance of various aetiologies; meanwhile, recent reports have focused on its immunomodulatory and anti-inflammatory properties. It is noteworthy that SPC, being simple cereal kernels, may have a positive image in the eyes of modern European consumers, who are increasingly sensitive to ethical considerations and whose opinion has a great influence on legislation ${ }^{(108)}$. Compared with other feed additives, SPC do not contain any active compound, since their action is to stimulate the animals' capability to produce AF. In addition, they do not pose any environmental harm such as the use of molecules such as $\mathrm{ZnO}$ that, even with improved growth promoting and antidiarrhoeic properties, accumulate in the soil ${ }^{(109)}$. In our field trial, we showed that an AF-inducing diet was effective in improving growth performance and feed conversion rate. It is well known that a more efficient use of nutrients present in the diet leads to decreased nutrition costs and to a reduction of $\mathrm{N}$ and phosphate excretion in manure and their accumulation in the soil.

The mechanism of action behind its biological activity has not yet been clarified and, so far, few data are available on pig field trials. Moreover, compared with its use in human nutrition, the proper level of diet supplementation has not been defined and further studies are required.

\section{Acknowledgements}

We wish to thank Professor T. Niewold for his availability and his supervision on the in vitro experiments on macrophages cited in the text. We also thank Professor 
Gianfranco Piva for his advice during the elaboration of this paper.

All authors contributed equally to the preparation of this paper.

The authors have no conflicts of interest, financial or otherwise, to disclose.

This research received no specific grant from any funding agency in the public, commercial or not-for-profit sectors.

\section{References}

1. Lönnroth I, Lange S \& Skadhauge E (1988) The antisecretory factors: inducible proteins which modulate secretion in the small intestine. Comp Biochem Physiol 90, 611-617.

2. Johansson E, Lönnroth I, Lange S, et al. (1995) Molecular cloning and expression of a pituitary gland protein modulating intestinal fluid secretion. J Biol Chem 270, 20615-20620.

3. Lange S, Jennische E, Johansson E, et al. (1999) The antisecretory factor: synthesis and intracellular localization in porcine tissues. Cell Tissue Res 296, 607-617.

4. Johansson E, Jennische E, Lange S, et al. (1997) Antisecretory factor suppresses intestinal inflammation and hypersecretion. Gut 41, 642-645.

5. Lange S \& Lönnroth I (2001) The antisecretory factor: synthesis, anatomical and cellular distribution, and biological action in experimental and clinical studies. Int Rev Cyt 210, 39-75.

6. Lange S (1982) A rat model for an in vivo assay of enterotoxic diarrhoea. FEMS Microbiol Lett 15, 239-242.

7. Rapallino MV, Cupello A, Lange S, et al. (2003) Antisecretory factor peptide derivatives specifically inhibit $\left[{ }^{3} \mathrm{H}\right]$ - $\gamma$-amino-butyric acid $/{ }^{36} \mathrm{Cl}^{-}$out $\rightarrow$ in permeation across the isolated rabbit Deiters' neuronal membrane. Acta Physiol Scand 179, 367-371.

8. Davidson TS \& Hickey WF (2004) Distribution and immunoregulatory properties of antisecretory factor. $L a b$ Invest 84, 307-319.

9. Björck S, Bosaeus I, Ek E, et al. (2000) Food induced stimulation of the antisecretory factor can improve symptoms in human inflammatory bowel disease: a study of a concept. Gut 46, 824-829.

10. United Nations (2008) United Nations Millennium Development Goals. http://www.un.org/millenniumgoals (accessed November 2009).

11. Bryce J, Boschi-Pinto C, Shibuya K, et al. (2005) WHO Child Health Epidemiology Reference Group. WHO estimates of the causes of death in children. Lancet $\mathbf{3 6 5}$, 1147-1152.

12. Zaman S, Mannana J, Lange S, et al. (2007) B 221, a medical food containing antisecretory factor reduces child diarrhoea - a placebo controlled trial. Acta Paediatr 96, $1655-1659$.

13. Laurenius A, Wängberg B, Lange S, et al. (2003) Antisecretory factor counteracts secretory diarrhoea of endocrine origin. Clin Nutr 22, 549-552.

14. Lallès JP, Bosi P, Janczyk P, et al. (2009) Impact of bioactive substances on the gastrointestinal tract and performance of weaned piglets: a review. Animal 3, 1625-1643.

15. Berkeveld M, Langendijk P, Soede NM, et al. (2009) Improving adaptation to weaning: effect of intermittent suckling regimens on piglet feed intake, growth, and gut characteristics. J Anim Sci 87, 3156-3166.
16. Jennische E, Hanner P, Johansson E, et al. (2003) Antisecretory factor in the human cochlea and saccus endolymphaticus. Exp Clin Endocrinol Diabetes 111, 401-405.

17. Johansson E, Lange S \& Lönnroth I (1997) Identification of an active site in the antisecretory factor protein. Biochim Biophys Acta 1362, 177-182.

18. Johansson E, Jonson I, Bosaeus M, et al. (2008) Identification of flotillin-1 as an interacting protein for antisecretory factor. Regul Pept 146, 303-309.

19. Vassileva EV, Ivanov AI \& Nusrat A (2008) Flotillin-1 stabilizes caveolin-1 in intestinal epithelial cells. Biochem Biophys Res Commun 379, 460-465.

20. Langhorst MF, Reuter A \& Stuermer CA (2005) Scaffolding microdomains and beyond: the function of reggie/flotillin proteins. Cell Mol Life Sci 62, 2228-2240.

21. Babuke T \& Tikkanen R (2007) Dissecting the molecular function of reggie/flotillin proteins. Eur J Cell Biol 86, $525-532$.

22. Allen JA, Halverson-Tamboli RA \& Rasenick MM (2007) Lipid raft microdomains and neurotransmitter signalling. Nat Rev Neurosci 8, 128-140.

23. Rossy J, Schlicht D, Engelhardt B, et al. (2009) Flotillins interact with PSGL-1 in neutrophils and, upon stimulation, rapidly organize into membrane domains subsequently accumulating in the uropod. PLoS ONE 4, e5403.

24. Katoh S, Kamimoto T, Yamakawa D, et al. (2009) Lipid rafts serve as signaling platform for Tie2 receptor tyrosine kinase in vascular endothelial cells. Exp Cell Res 315, 2818-2823.

25. Morgan MJ, Kim YS \& Liu Z (2007) Lipid rafts and oxidative stress-induced cell death. Antioxid Redox Signal 9, 1471-1483.

26. Van der Goot FG \& Harder T (2001) Raft membrane domains: from a liquid-ordered membrane phase to a site of pathogen attack. Semin Immunol 13, 89-97.

27. Li N, Mak A, Richards DP, et al. (2003) Monocyte lipid rafts contain proteins implicated in vesicular trafficking and phagosome formation. Proteomics 3, 536-548.

28. Davidson TS \& Hickey WF (2004) Antisecretory factor expression is regulated by inflammatory mediators and influences the severity of experimental autoimmune encephalomyelitis. J Leukoc Biol 76, 835-844.

29. Hickey WF \& Kimura H (1988) Perivascular microglial cells of the CNS are bone marrow derived and present antigen in vivo. Science 239, 290-292.

30. Fujiwara N \& Kobayashi K (2005) Macrophages in inflammation. Curr Drug Targets Inflamm Allergy 4, 281-286.

31. Galofré M, Babot Z, García DA, et al. (2009) $\mathrm{GABA}_{\mathrm{A}}$ receptor and cell membrane potential as functional endpoints in cultured neurons to evaluate chemicals for human acute toxicity. Neurotoxicol Teratol 32, 52-61.

32. Madsen KK, Larsson OM \& Schousboe A (2008) Regulation of excitation by GABA neurotransmission: focus on metabolism and transport. Results Probl Cell Differ 44, 201-221.

33. Medina I \& Chudotvorova I (2006) GABA neurotransmission and neural cation-chloride co-transporters: actions beyond ion transport. Crit Rev Neurobiol 18, 105-112.

34. Leist M \& Nicotera P (1998) Apoptosis, excitotoxicity, and neuropathology. Exp Cell Res 239, 183-201.

35. Olney JW (2002) New insights and new issues in developmental neurotoxicology. Neurotoxicology 23, 659-668. 
36. Lange S, Lönnroth I, Palm A, et al. (1985) An inhibitory protein of intestinal fluid secretion reverses neuronal GABA transport. Biochem Biophys Res Commun 130, 1032-1036.

37. Lange S, Lönnroth I, Palm A, et al. (1987) The effect of antisecretory factor on the permeability of nerve cell membrane to chloride ion. Pflügers Arch 410, 648-651.

38. Kim M, Wasling P, Xiao MY, et al. (2005) Antisecretory factor modulates GABAergic transmission in the rat hippocampus. Regul Pept 129, 109-118.

39. Gwynne RM \& Bornstein JC (2007) Local inhibitory reflexes excited by mucosal application of nutrient amino acids in guinea pig jejunum. Am J Physiol Gastrointest Liver Physiol 292, G1660-G1670.

40. Krantis A (2000) GABA in the mammalian enteric nervous system. News Physiol Sci 15, 284-290.

41. Minocha A \& Galligan JJ (1993) Excitatory and inhibitory responses mediated by $\mathrm{GABA}_{\mathrm{A}}$ and $\mathrm{GABA}_{\mathrm{B}}$ receptors in guinea pig distal colon. Eur J Pharmacol 230, 187-193.

42. Bayer S, Crenner F, Aunis D, et al. (2002) Effects of GABA on circular smooth muscle spontaneous activities of rat distal colon. Life Sci 71, 911-925.

43. Harrison AP, Bartels EM, Erlwanger KH, et al. (2004) Effects of antisecretory factor-derived peptides on contractions in guinea pig colon. Comp Biochem Physiol A 139, $143-148$.

44. Göransson L (1997) Alternatives to antibiotics - the influence of new feeding strategies for pigs on biology and performance. In Recent Advances in Animal Nutrition, pp. 45-56 [PC Garnsworthy and J Wiseman, editors]. Nottingham, UK: Nothingham University Press.

45. Sigfridsson K, Lange S \& Lönnroth I (1995) Anti secretory factor (ASF) and feed induced lectines (FIL) in sow and suckling piglet. In Book of Abstracts of the 46th Annual Meeting of the European Association for Animal Production $(E A A P)$, p. 165, poster M 4.23 [JAM van Arendonk, editor]. Wageningen: Wageningen Press, Prague, September 1995.

46. Lange S, Martinsson K, Lönnroth I, et al. (1993) Plasma level of antisecretory factor (ASF) and its relation to postweaning diarrhoea in piglets. $J$ Vet Med B 40, 13-18.

47. Lönnroth I \& Lange S (1987) Intake of monosaccharides or aminoacids induces pituitary gland synthesis of proteins regulating intestinal fluid transport. Biochim Biophys Acta 925, 117-123.

48. Göransson L, Martinsson K, Lange S, et al. (1993) Feed-induced lectins in piglets. Feed-induced lectins and their effect on post weaning diarrhoea, daily weight gain and mortality. $J$ Vet Med B 40, 478-484.

49. Lange S, Lönnroth I \& Martinsson K (1994) Concentrations of antisecretory factor in eggs and in chicken blood plasma. Br Poult Sci 35, 615-620.

50. Eriksson A, Shafazand M, Jennische E, et al. (2003) Effect of antisecretory factor in ulcerative colitis on histological and laborative outcome: a short period clinical trial. Scand $J$ Gastroenterol 38, 1045-1049.

51. Eriksson A, Shafazand M, Jennische E, et al. (2003) Antisecretory factor-induced regression of Crohn's disease in a weak responder to conventional pharmacological treatment. Infl Bow Dis 9, 398-400.

52. Wapnir RA \& Teichberg S (2002) Regulation mechanisms of intestinal secretion: implications in nutrient absorption. J Nutr Biochem 13, 190-199.

53. Lundgren O (2002) Enteric nerves and diarrhoea. Pharmacol Toxicol 90, 109-120.

54. Fordtran J (1967) Speculation on the pathogenesis of diarrhoea. Fed Proc 26, 1405-1414.
55. Petri WA Jr, Miller M, Binder HJ, et al. (2008) Enteric infections, diarrhoea, and their impact on function and development. J Clin Invest 118, 1277-1290.

56. Field M, Fromm D, al-Awqati Q, et al. (1972) Effect of cholera enterotoxin on ion transport across isolated ileal mucosa. J Clin Invest 51, 796-804.

57. Fan E, O'Neal CJ, Mitchell DD, et al. (2004) Structural biology and structure-based inhibitor design of cholera toxin and heat-labile enterotoxin. Int J Med Microbiol 294, $217-223$

58. Griffiths SL \& Critchley DR (1991) Characterization of the binding sites for Escherichia coli heat-labile toxin type I in intestinal brush borders. Biochim Biophys Acta $\mathbf{1 0 7 5}$ 154-161.

59. Mourad FH, O’Donnell LJ, Dias JA, et al. (1995) Role of 5-hydroxytryptamine type 3 receptors in rat intestinal fluid and electrolyte secretion induced by cholera and Escherichia coli enterotoxins. Gut 37, 340-345.

60. Moss J \& Vaughan M (1981) Mechanism of action of choleragen and E. coli heat-labile enterotoxin: activation of adenylate cyclase by ADP-ribosylation. Mol Cell Biochem 37, 75-90.

61. Cooke HJ (1994) Neuroimmune signaling in regulation of intestinal ion transport. Am J Physiol 266, G167-G178.

62. Cassuto J, Fahrenkrug J, Jodal M, et al. (1981) Release of vasoactive intestinal polypeptide from the cat small intestine exposed to cholera toxin. Gut 22, 958-963.

63. Holmgren J \& Svennerholm AM (1992) Bacterial enteric infections and vaccine development. Gastroenterol Clin North Am 21, 283-302.

64. Horstman AL \& Kuehn MJ (2000) Enterotoxigenic Escherichia coli secretes active heat-labile enterotoxin via outer membrane vesicles. J Biol Chem 275, 12489-12496.

65. Kuehn MJ \& Kesty NC (2004) Bacterial outer membrane vesicles and the host-pathogen interaction. Genes Dev 19 , 2645-2655.

66. Holmner A, Askarieh G, Okvist M, et al. (2007) Blood group antigen recognition by Escherichia coli heat-labile enterotoxin. J Mol Biol 371, 754-764.

67. Lönnroth I, Lange S, Jennische E, et al. (2003) Cholera toxin protects against action by Clostridium difficile toxin A. The role of antisecretory factor in intestinal secretion and inflammation in rat. APMIS 111, 969-977.

68. Kelly CP \& La Mont JT (1998) Clostridium difficile infection. Annu Rev Med 49, 375-390.

69. Lorrot M \& Vasseur M (2007) How do the rotavirus NSP4 and bacterial enterotoxins lead differently to diarrhea? Virol J 21, 4-31.

70. Kotloff KL, Winickoff JP, Ivanoff P, et al. (1999) Global burden of Shigella infections: implications for vaccine development and implementation of control strategies. Bull World Health Organ 77, 651-666.

71. Baldi F, Bianco MA, Nardone G, et al. (2009) Focus on diarrhoeal disease. World J Gastroenterol 15, 3341-3348.

72. Torres J, Jennische E, Lange S, et al. (1991) Clostridium difficile toxin A indues a specific antisecretory factor which protects against intestinal mucosal damage. Gut 32, 791-795.

73. Grøndahl ML, Sorensen H, Unmack MA, et al. (2002) Neuronal involvement in the effect of an antisecretory factor-derived peptide on induced secretion in the porcine small intestine. J Comp Physiol A 188, 589-594.

74. Goyal RK \& Hirano I (1996) The enteric nervous system. $N$ Engl J Med 334, 1106-1114.

75. Johansson E, Lönnroth I, Jonson I, et al. (2009) Development of monoclonal antibodies for detection of 
antisecretory factor activity in human plasma. J Immunol Methods 342, 64-70.

76. Jennische E, Johansson E, Hansson HA, et al. (2006) Immunohistochemical staining patterns using epitopespecific antibodies indicate conformation variants of antisecretory factor/S5a in the CNS. APMIS 114, 529-538.

77. Ferguson LR, Shelling AN, Browning BL, et al. (2007) Genes, diet and inflammatory bowel disease. Mutat Res 622 , 70-83.

78. Fiasse R, Denis MA \& Dewit O (2010) Chronic inflammatory bowel disease: Crohn's disease and ulcerative colitis (article in French). J Pharm Belg 1, 1-9.

79. Levy RL, Olden KW \& Naliboff BD (2006) Psychosocial aspects of the gastrointestinal disorders. Gastroenterology 130, 1447-1458.

80. Jess T, Riis L, Jespersgaard C, et al. (2005) Disease concordance, zygosity, and NOD2/CARD15 status: followup of a population-based cohort of Danish twins with inflammatory bowel disease. Am J Gastroenterol 100, 2486-2492.

81. Loftus EV Jr, Silverstein MD, Sandborn WJ, et al. (1998) Crohn's disease in Olmsted County, Minnesota, 19401993: incidence, prevalence, and survival. Gastroenterology 114, 1161-1168.

82. Ekesbo R, Nilsson PM \& Sjölund K (2008) Effects of antisecretory factor (ASF) on irritable bowel disease. Scand J Primary Health Care 26, 106-110.

83. Tilg H (2008) Short bowel syndrome: searching for the proper diet. Eur J Gastroenterol Hepatol 20, 1061-1063.

84. Messing B, Crenn P, Beau P, et al. (1999) Long-term survival and parenteral nutrition dependence in adult patients with the short bowel syndrome. Gastroenterology 117, 1043-1050.

85. Nightingale JM (2001) Management of patients with short bowel. World J Gastroenterol 7, 741-751.

86. Lange S, Bosaeus I, Jennische E, et al. (2003) Food-induced antisecretory factor activity is correlated to small bowel length in patients with intestinal resections. APMIS 111, 985-988.

87. Pagoldh M, Eriksson A, Heimtun E, et al. (2008) Effects of supplementary diet with specially processed cereals in patients with short bowel syndrome. Eur J Gastroenterol Hepatol 20, 1085-1093.

88. Dodi G \& Spencer R (1996) Diarrhoea. In Outpatient Coloproctology, textbook and color atlas, pp. 486-489. Padova, Italy: Piccin Nuova Libraria.

89. O'Toole D, Ducreux M, Bommelaer G, et al. (2000) Treatment of carcinoid syndrome: a prospective crossover evaluation of lanreotide versus octreotide in terms of efficacy, patient acceptability, and tolerance. Cancer $\mathbf{8 8}$ 770-776.

90. Kaltsas GA, Besser GM \& Grossman AB (2004) The diagnosis and medical management of advanced neuroendocrine tumors. Endocr Rev 25, 458-511.

91. Flemming JB, Lee JE, Bouvet M, et al. (1999) Surgical strategy for the treatment of medullary thyroid carcinoma. Ann Surg 230, 697-707.

92. Wängberg B, Westberg G, Thylen U, et al. (1996) Survival of patients with disseminated midgut carcinoid tumors after aggressive tumor reduction. World J Surg 20, 892-899.

93. Brown KH (1990) Epidemiological relationship between malnutrition and chronic diarrhoea in infants and children. In Malnutrition in Chronic Diet-Associated Infantile Diarrhoea. Diagnosis and Management, pp. 209-234
[CH Lifschitz and B Nicols, editors]. San Diego, CA: Academic Press.

94. Mihrshahi S, Oddy WH, Peat JK, et al. (2008) Association between infant feeding patterns and diarrhoeal and respiratory illness: a cohort study in Chittagong, Bangladesh. Int Breastfeed J 3, 28.

95. Ziyane IS (1999) The relationship between infant feeding practices and diarrhoeal infections. $J$ Adv Nurs 29, $721-726$.

96. Saleemi MA, Zaman S, Akhtar HZ, et al. (2004) Feeding patterns, diarrhoeal illness and linear growth in 0-24month-old children. J Trop Pediatr 50, 164-169.

97. Svensson K, Lange S, Lönnroth I, et al. (2004) Induction of antisecretory factor in human milk may prevent mastitis. Acta Padiatr 93, 1228-1231.

98. Hanner P, Jennische E, Lange S, et al. (2004) Increased antisecretory factor reduces vertigo in patients with Meniere's disease: a pilot study. Hear Res 190, 31-36.

99. Hanner P, Rask-Andersen H, Lange S, et al. (2010) Antisecretory factor-inducing therapy improves the clinical out come in patients with Ménière's disease. Acta Otolaryngol 28, 223-227.

100. Vink R, Young A, Bennett CJ, et al. (2003) Neuropeptide release influences brain edema formation after diffuse traumatic brain injury. Acta Neurochir Suppl 86, 257-260.

101. Hoane MR, Kaplan SA \& Ellis AL (2006) The effects of nicotinamide on apoptosis and blood-brain barrier breakdown following traumatic brain injury. Brain Res $\mathbf{1 1 2 5}$, $185-193$.

102. Säljö A, Svensson B, Mayorga M, et al. (2009) Low levels of blast raises intracranial pressure and impairs cognitive function in rats. $J$ Neurotrauma 27, 1345-1352.

103. Säljö A, Bolouri H, Mayorga M, et al. (2010) Low levels of blast raises intracranial pressure and impairs cognitive function in rats: prophylaxis with fermented cereal feed. J Neurotrauma 27, 383-389.

104. Jennische E, Bergström T, Johansson M, et al. (2008) The peptide AF-16 abolishes sickness and death at experimental encephalitis by reducing increase of intracranial pressure. Brain Res 1227, 189-197.

105. Armonda RA, Bell RS, Vo AH, et al. (2006) Wartime traumatic cerebral vasospasm: recent review of combat casualties. Neurosurgery 59, 1215-1225.

106. Jantzen JP (2007) Prevention and treatment of intracranial hypertension. Best Pract Res Clin Anaesthesiol 21, 517-538.

107. Gallois M, Rothköttera HJ, Baileya M, et al. (2009) Natural alternatives to in-feed antibiotics in pig production: can immunomodulators play a role? Animal 3, 1644-1661.

108. Florkowski WJ, Elnagheeb AH \& Huang CL (1998) Risk perception and new food production technologies. Appl Econ Lett 5, 69-73.

109. Jondreville C, Revy PS \& Dourmad JY (2003) Dietary means to better control the environmental impact of copper and zinc by pigs from weaning to slaughter. Livest Prod Sci 84, 147-156.

110. Ulgheri C, Grilli E, Rossi F, et al. (2010) Effect of hydrothermally processed cereals on the performance of weaned piglets. Livest Sci (epublication ahead of print version).

111. Finkel Y, Bjarnason I, Lindblad A, et al. (2004) Specially processed cereals: a clinical innovation for children suffering from inflammatory bowel disease? Scand $J$ Gastroenterol 39, 87-88. 